\title{
Advanced glycation end products inhibit testosterone secretion by rat Leydig cells by inducing oxidative stress and endoplasmic reticulum stress
}

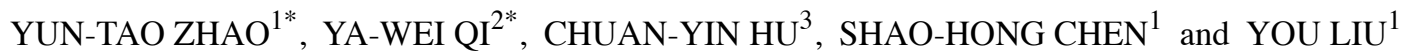 \\ ${ }^{1}$ Modern Biochemistry Center, Guangdong Ocean University, Zhanjiang, Guangdong 524088; ${ }^{2}$ Institute of Plastic Surgery, \\ Affiliated Hospital of Guangdong Medical College, Zhanjiang, Guangdong 524001; ${ }^{3}$ Department of Biology, \\ Guangdong Medical College, Zhanjiang, Guangdong 524023, P.R. China
}

Received November 4, 2015; Accepted June 7, 2016

DOI: $10.3892 / \mathrm{ijmm} .2016 .2645$

\begin{abstract}
Diabetes severely impairs male reproduction. The present study assessed the effects and mechanisms of action of advanced glycation end products (AGEs), which play an important role in the development of diabetes complications, on testosterone secretion by rat Leydig cells. Primary rat Leydig cells were cultured and treated with AGEs (25, 50, 100 and $200 \mu \mathrm{g} /$ $\mathrm{ml})$. Testosterone production induced by human chorionic gonadotropin (hCG) was determined by ELISA. The mRNA and protein expression levels of steroidogenic acute regulatory protein (StAR), cholesterol side-chain cleavage enzyme (P450scc) and $3 \beta$-hydroxysteroid dehydrogenase (3 $\beta$-HSD), which are involved in testosterone biosynthesis, were measured by reverse transcription-quantitative PCR and western blot analyssi, respectively. Reactive oxygen species (ROS) production in Leydig cells was measured using the dichlorofluorescein diacetate (DCFH-DA) probe. The expression levels of endoplasmic reticulum stress-related proteins [C/EBP homologous protein (CHOP) and glucose-regulated protein 78 (GRP78)] in the Leydig cells were measured by western blot analysis. We found that the AGEs markedly suppressed testosterone production by rat Leydig cells which was induced by hCG in a concentration-dependent manner compared with the control $(\mathrm{P}<0.01)$. The mRNA and protein expression levels of StAR, 3 $\beta$-HSD and P450scc were downregulated by the AGEs in a dose-dependent manner compared with the control $(\mathrm{P}<0.01)$. The antioxidant agent, $\mathrm{N}$-acetyl-L-cysteine (NAC), and the endoplasmic reticulum stress inhibitor, tauroursodeoxycholic acid (TUDCA), reversed the inhibitory effects of AGEs. In
\end{abstract}

Correspondence to: Professor You Liu, Modern Biochemistry Center, Guangdong Ocean University, 1 Hai-Da Road, Zhanjiang, Guangdong 524088, P.R. China

E-mail: liuy6254282@163.com

*Contributed equally

Key words: advanced glycation end products, Leydig cells, testosterone, oxidative stress, endoplasmic reticulum stress addition, the content of ROS in Leydig cells treated with AGEs increased significantly. The expression levels of CHOP and GRP78 were markedly upregulated by the AGEs in the Leydig cells. From these findings, it can be concluded that AGEs inhibit testosterone production by rat Leydig cells by inducing oxidative stress and endoplasmic reticulum stress.

\section{Introduction}

According to the Diabetes Atlas of the International Diabetes Federation, 382 million individuals were affected by diabetes worldwide in 2013 and its prevalence is expected to increase to 592 million by the year 2035 (1). With the increasing prevalence of diabetes in children and adolescents, male reproductive dysfunction induced by diabetes has attracted worldwide attention (2-5).

Numerous studies have demonstrated that male reproductive dysfunction induced by diabetes may be mediated through hormonal alterations in the hypothalamic-pituitary-gonadal axis or through direct effects on testes, sperm, epididymis and Sertoli-blood testis barrier. Diabetes impairs spermatogenesis, increases germ cell depletion, alters sperm parameters, induces morphological alterations in the testes, alters glucose metabolism in the Sertoli-blood testis barrier, reduces testosterone production, leads to ejaculatory dysfunction and reduces libido (6-15). However, the underlying mechanisms of diabetesrelated male reproductive dysfunction remain largely unknown.

Increasing evidence has indicated that advanced glycation end products (AGEs) play a causative role in the progression of diabetes complications (16-18). AGEs are a heterogeneous class of compounds formed by the non-enzymatic glycation of proteins, which is accelerated in diabetes as a result of hyperglycaemia and oxidative stress. The receptor for AGEs (RAGE) exists in the testes, epididymides and sperm $(19,20)$. $\mathrm{N}$-carboxymethyl-lysine, a prominent AGE, accumulates in the reproductive tract of patients with diabetes (21), as well as in animal models of both diabetes (22) and metabolic syndrome (23). Men suffering from diabetes have poor sperm quality and functions, coinciding with the increase in AGEs and RAGE $(21,24,25)$. These studies show that AGEs play important roles in male reproduction dysfunction induced by diabetes. 
To date, the mechanism underlying the low testosterone levels associated with diabetes has not been fully elucidated $(26,27)$. As AGEs are important instigators of diabetes complications, we hypothesized that these compounds possibly play a contributory role in testosterone production by affecting Leydig cells directly. Thus, the aim of this study, was to determine whether AGEs exert inhibitory effects on testosterone secretion by rat Leydig cells. In addition, the possible mechanisms responsible for these effects were investigated.

\section{Materials and methods}

Animals. Male Sprague-Dawley rats (7-8 weeks old, weighing 250-300 g) were purchased from the Guangdong Medical Laboratory Animal Center of China. The animals were kept in a temperature-controlled room $\left(20^{\circ} \mathrm{C}\right)$ with a $12 \mathrm{~h}$-light/12 h-dark photoperiod and were give access to food and water ad libitum. All animal experiments were performed in accordance with the guidelines of the Guangdong Ocean University Animal Use Committee, and the protocols were approved by the Animal Ethics and Welfare Committee of Guangdong Ocean University (Approval No. 2014031903).

Materials. Dulbecco's modified Eagle's medium/nutrient mixture F-12 (DMEM/F12), fetal bovine serum (FBS), Hanks and penicillin/streptomycin were purchased from Gibco Laboratories (Grand Island, NY, USA). Bovine serum albumin (BSA), tauroursodeoxycholic acid (TUDCA), $\mathrm{N}$-acetyl-L-cysteine (NAC) and collagenase were obtained from Sigma-Aldrich (St. Louis, MO, USA). Percoll ${ }^{\mathrm{TM}}$ (Sterile) was obtianed from GE Healthcare (Pittsburgh, PA, USA). The testosterone ELISA kit was purchased from Cayman Chemical Co. (Ann Arbor, MI, USA). Anti-steroidogenic acute regulatory protein (StAR; Cat. no. sc-25806), anti-cholesterol side-chain cleavage enzyme (P450scc; Cat. no. sc-292456), anti$3 \beta$-hydroxysteroid dehydrogenase ( $3 \beta$-HSD; Cat. no. sc-30820), anti-glucose-regulated protein 78 (GRP78; Cat. no. sc-13968), and anti-C/EBP homologous protein (CHOP; Cat. no. sc-166682) antibodies were obtained from Santa Cruz Biotechnology (Santa Cruz, CA, USA); anti-actin (Cat. no. \#4970) and antirabbit IgG (Cat. no. \#7074) were obtained from Cell Signaling Technology, Inc. (Danvers, MA, USA). The endotoxin assay kit was purchased from Jinruisi Inc. (Nanjing, China). The bicinchoninic acid (BCA) protein assay kit was obtained from Shenenergy Inc. (Shanghai, China). TRIzol was purchased from Invitrogen Life Technologies (Carlsbad, CA, USA). M-MLV reverse transcriptase was obtained from Promega (Madison, WI, USA). SYBR Premix Ex Taq ${ }^{\mathrm{TM}}$ was obtained from Takara Biot echnology Co., Ltd. (Dalian, China). ECL chemiluminescent substrate was obtained from Millipore (Billerica, MA, USA).

Preparation of AGEs. The AGEs were prepared as previously described (28). Briefly, fatty acid-free BSA was incubated with $50 \mathrm{mM}$ D-glucose in phosphate-buffered saline (PBS) solution in the dark and under ysterile conditions for 7 weeks at $37^{\circ} \mathrm{C}$. Unincorporated glucose was removed by dialysis with PBS. Control non-glycated BSA was incubated in the absence of glucose under the same conditions. AGE-BSA solutions were tested for endotoxin concentrations and confirmed to be endotoxin free $(<2.5 \mathrm{U} / \mathrm{ml}$ of endotoxin).
Culture of primary rat Leydig cells. Rat Leydig cells were isolated from the testes of mature rats as previously described $(29,30)$ with some modifications. Briefly, male Sprague-Dawley rats were sacrificed by $\mathrm{CO}_{2}$ inhalation. The testes were quickly removed, decapsulated and placed in a $50-\mathrm{ml}$ plastic tube containing $3 \mathrm{ml}$ of collagenase solution $(0.5 \mathrm{mg} / \mathrm{ml})$ and incubated in an oscillating incubator $\left(100 \mathrm{r} / \mathrm{min}, 34^{\circ} \mathrm{C}\right)$ for $30 \mathrm{~min}$. The cell suspension was transferred to a $50-\mathrm{ml}$ tube and kept on ice for $2 \mathrm{~min}$ to allow the tubules to settle. The supernatant containing Leydig cells was filtered through a $100-\mu \mathrm{m}$ nylon cell strainer (BD Biosciences, San Jose, CA, USA). The cells were centrifuged at $1,500 \mathrm{rpm}$ for $10 \mathrm{~min}$ at $4^{\circ} \mathrm{C}$. The pellet was resuspended in $2 \mathrm{ml} \mathrm{DMEM} / \mathrm{F} 12$ and loaded onto the top of the discontinuous Percoll gradient $(21,26,37$ and 60\%) and centrifuged at $3,000 \mathrm{rpm}$ for $30 \mathrm{~min}$ at $4^{\circ} \mathrm{C}$. The cells in the interphase between 37 and $60 \%$ were collected and maintained in DMEM/F12 medium containing 10\% FBS, $100 \mathrm{U} / \mathrm{ml}$ penicillin and $100 \mathrm{mg} / \mathrm{ml}$ streptomycin at $34^{\circ} \mathrm{C}$ with $5 \% \mathrm{CO}_{2}$. The purity of the Leydig cells was examined by $3 \beta$-hydroxysteroid staining and $>90 \%$ of the cells stained positive (data not shown).

Determination of cell viability. The effects of AGEs on Leydig cell viability were evaluated by 3-(4,5-dimethylthiazol-2-yl)2,5-diphenyltetrazolium bromide (MTT) assay. Rat Leydig cells were plated into 96-well culture plates. Following $48 \mathrm{~h}$ of incubation with various concentrations of AGEs $(25,50,100$ and $200 \mu \mathrm{g} / \mathrm{ml}), 100 \mu \mathrm{l}$ MTT $(5 \mathrm{mg} / \mathrm{ml})$ were added to each well and the cells were incubated for $2 \mathrm{~h}$ at $34^{\circ} \mathrm{C}$. The medium was discarded and $150 \mu \mathrm{l}$ DMSO was then added to each well. The absorbance was measured at $490 \mathrm{~nm}$ using a microplate reader. The results were expressed as the percentage of MTT reduction, assuming that the absorbance of the control cells was $100 \%$.

Measurement of testosterone concentration. The rat Leydig cells cultured in 6-well plates were pre-incubated with various concentrations of AGEs or BSA for $12 \mathrm{~h}$ and the culture medium was replaced with fresh medium containing human chorionic gonadotropin (hCG; $4 \mathrm{ng} / \mathrm{ml}$ ) with or without the same concentrations AGEs or BSA. Following treatment under different conditions for $12 \mathrm{~h}$, the medium was collected and centrifugated $12,000 \mathrm{rpm}$ for $5 \mathrm{~min}$ at $4^{\circ} \mathrm{C}$, and the supernatant were collected and assayed for testosterone using ELISA kit. The sensitivity of the assay was $32 \mathrm{pg} / \mathrm{ml}$. Intra- and inter-assay variations were below 6.6 and $7.5 \%$, respectively.

Measurement of intracellular reactive oxygen species (ROS). Intracellular ROS levels were determined by measuring the probe, dichlorofluorescein diacetate (DCFH-DA). Briefly, cells treated with or without AGEs for $12 \mathrm{~h}$ were washed and incubated with fresh medium containing $10 \mu \mathrm{M}$ DCFH-DA for $30 \mathrm{~min}$ in the dark. The medium was then removed and the cells were washed with PBS. Fluorescence at excitation, $485 \mathrm{~nm}$ and emission, $535 \mathrm{~nm}$ was measured using a microplate reader (TriStar LB941; Berthold Technologies, Oak Ridge, TN, USA).

$R N A$ isolation and reverse transcription-quantitative PCR $(R T-q P C R)$. The Leydig cells were treated under different conditions and total RNA was then isolated using TRIzol reagent following the manufacturer's instructions. cDNA was synthesized from $1 \mu \mathrm{g}$ of total RNA using M-MLV reverse 
transcriptase in a total reaction volume of $20 \mu \mathrm{l}$. The PCR reaction mixtures contained $10 \mu 1 \mathrm{SYBR}^{\circledR}$ Premix Ex Taq $^{\mathrm{TM}}$, $0.4 \mu \mathrm{l}$ of each primer $(10 \mu \mathrm{M}), 2 \mu \mathrm{l}$ template cDNA and $\mathrm{dH}_{2} \mathrm{O}$ up to a final volume of $20 \mu \mathrm{l}$. The cycling conditions were $94^{\circ} \mathrm{C}$ for $40 \mathrm{sec}$, followed by 40 cycles of $94^{\circ} \mathrm{C}$ for $15 \mathrm{sec}, 64^{\circ} \mathrm{C}$ for $15 \mathrm{sec}$, and $72^{\circ} \mathrm{C}$ for $15 \mathrm{sec}$. The following primers were used: StAR forward, 5'-ACCACATCTACCTGCACGCCAT-3' and reverse, 5'-CCTCTCGTTGTCCTTGGCTGAA-3'; 3 $\beta$-HSD forward, 5'-AGCAAAAAGATGGCCGAGAA-3' and reverse, 5'-GGCACAAGTATGCAATGTGCC-3'; P450sce forward, 5'-TTCCCATGCTCAACATGCCTC-3' and reverse, 5'-ACTGAAAATCACATCCCAGGCAG-3'; $\beta$-actin forward, 5'-GGAAATCGTGCGTGACATTAAAG-3' and reverse, 5'-CGGCAGTGGCCATCTCTT-3'. The relative gene expression levels were normalized to $\beta$-actin using the $\Delta \Delta \mathrm{Ct}$ method, where $\mathrm{Ct}$ was the cycle threshold.

Western blot analysis. After being subjected to the various treatments, the cells were washed twice with PBS and then lysed for $20 \mathrm{~min}$ in lysis buffer (50 mM Tris- $\mathrm{HCl}$, $\mathrm{pH} 7.5$, $250 \mathrm{mM} \mathrm{NaCl}, 2 \mathrm{mM}$ EDTA, $10 \%$ glycerol, $0.1 \% \mathrm{NP}-40$, $0.5 \mathrm{mM}$ PMSF, $10 \mu \mathrm{g} / \mathrm{ml}$ aprotinin, $10 \mu \mathrm{g} / \mathrm{ml}$ leupeptin, $1 \mathrm{mM} \mathrm{NaF}, 0.1 \mathrm{mM} \mathrm{Na}_{3} \mathrm{VO}_{4}$ and $1 \mathrm{mM}$ dithiothreitol). The protein concentration was measured by BCA protein assay. Protein $(30 \mu \mathrm{g})$ was separated by SDS-polyacrylamide gel electrophoresis, and transferred onto PVDF membranes. The membranes were blocked in 5\% non-fat milk powder in Tris-buffered saline (TBS)/0.1\% Tween-20 for $1 \mathrm{~h}$ at room temperature and incubated with specific antibodies (3 $\beta-\mathrm{HSD}$, P450scc, StAR, GRP78, CHOP, $\beta$-actin) in 5\% BSA in TBS at $4^{\circ} \mathrm{C}$ overnight. After washing, the membranes were incubated with HRP-conjugated second antibody in TBS for $1 \mathrm{~h}$ at room temperature. Finally, the labeled proteins were detected using the ECL kit. Densitometric analyses of the bands were performed using ImageJ software (obtained from the NIH websites, http://rsb.info.nih.gov/nih-image).

Statistical analysis. Statistical comparison was carried out using one-way analysis of variance (ANOVA). The data represent the means \pm SEM. Values of $\mathrm{P}<0.05$ were considered to indicate statistically significant differences.

\section{Results}

Effect of AGEs on the viability of rat primary Leydig cells. To assess the effect of AGEs on the viability of rat primary Leydig cells, the cells were treated with AGEs or BSA for $48 \mathrm{~h}$ and MTT assay was then performed. The viability of the cells treated with AGEs is shown in Fig. 1. The viability of the cells treated with $200 \mu \mathrm{g} / \mathrm{ml} \mathrm{BSA}$, or with $25,50,100$ and $200 \mu \mathrm{g} / \mathrm{ml}$ AGEs was 101.1 $\pm 9.2,99.0 \pm 7.7,96.8 \pm 9.3,96.0 \pm 10.3$ and $94.7 \pm 8.0 \%$ of the control value, respectively. These data indicated that the viability of the Leydig cells treated with AGEs (concentrations $\leq 200 \mu \mathrm{g} / \mathrm{ml}$ ) for $48 \mathrm{~h}$ was not significantly altered.

AGEs inhibits testosterone secretion by hCG-treated Leydig cells. The influence of AGEs on hCG-stimulated testosterone production in Leydig cells is illustrated in Fig. 2. Exposure to $\mathrm{hCG}$ at $4 \mathrm{U} / \mathrm{ml}$ induced a significant increase in testosterone

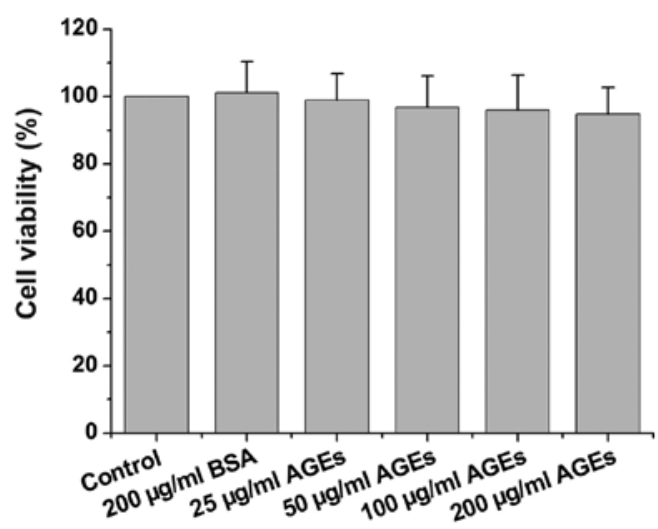

Figure 1. Effect of advanced glycation end products (AGEs) on the viability of rat Leydig cells. Rat Leydig cells were incubated with various concentrations of AGEs $(25 \mu \mathrm{g} / \mathrm{ml}, 50 \mu \mathrm{g} / \mathrm{ml}, 100 \mu \mathrm{g} / \mathrm{ml}$ and $200 \mu \mathrm{g} / \mathrm{ml})$ or bovine serum albumin (BSA) $(200 \mu \mathrm{g} / \mathrm{ml})$ for $48 \mathrm{~h}$ and cell viability was determined by MTT assay. Data are expressed as a percentage of the control. Data were obtained from 3 separate experiments.

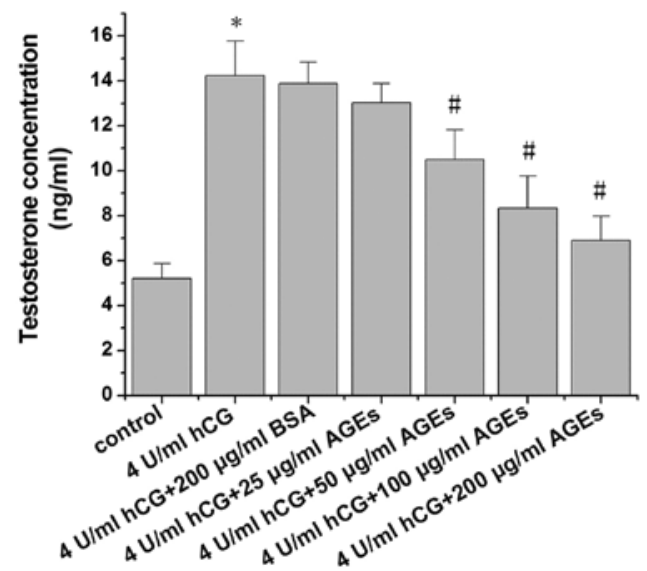

Figure 2. Effects of advanced glycation end products (AGEs) on testosterone secretion by rat Leydig cells. Leydig cells were incubated with various concentrations of AGEs for $24 \mathrm{~h}$ in the presence of human chorionic gonadotropin (hCG) $(4 \mathrm{U} / \mathrm{ml})$, and testosterone concentrations were then measured. Data are expressed as the means \pm SEM of 3 separate experiments. ${ }^{*} \mathrm{P}<0.01$ vs. control; ${ }^{\#} \mathrm{P}<0.01$ vs. $4 \mathrm{U} / \mathrm{ml}$ hCG treatment group.

secretion by rat Leydig cells $(\mathrm{P}<0.01)$. Following treatment with AGEs for $24 \mathrm{~h}$, testosterone secretion by the rat Leydig cells was reduced in a dose-dependent manner, with significant decreases being observed from the concentration of $50 \mu \mathrm{g} / \mathrm{ml}$ AGEs.

Effects of AGEs on the expression levels of StAR, P450scc and $3 \beta-H S D$. In order to examine the influence of AGEs on the transcriptional levels of genes related to the testosterone synthetic pathway in rat Leydig cells, the mRNA levels of StAR, P450scc and 3 $\beta$-HSD in rat Leydig cells treated with AGEs for $24 \mathrm{~h}$ were measured. Generally, treatment with AGEs led to a significant decrease in the mRNA levels of StAR, P450scc and 3 $\beta$-HSD (Fig. 3). Furthermore, the protein levels of StAR, P450scc and 3 $\beta$-HSD in the cells treated with AGEs for $24 \mathrm{~h}$ were investigated. The results revealed that AGEs decreased the StAR, P450scc and 3 $\beta$-HSD protein levels in a dose-dependent manner (Fig. 4). 


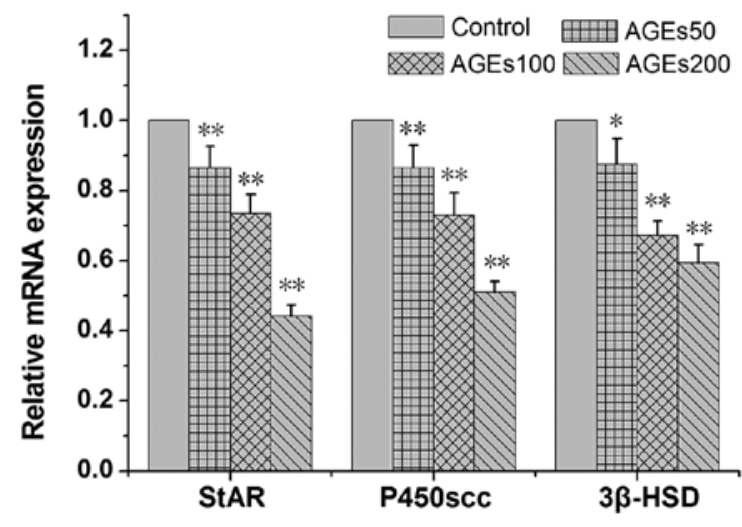

Figure 3. Effects of advanced glycation end products (AGEs) on the mRNA levels of steroidogenic acute regulatory protein (StAR), cholesterol side-chain

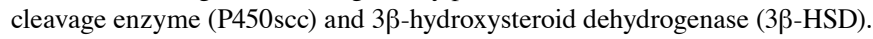
Rat Leydig cells were exposed to various concentrations of AGEs (50, 100 and $200 \mu \mathrm{g} / \mathrm{ml}$ ) for $24 \mathrm{~h}$ and the mRNA levels of StAR, P450scc and 3 $\beta$-HSD were analyzed by RT-qPCR. Data are expressed as the means \pm SEM of 3 separate experiments. ${ }^{*} \mathrm{P}<0.05$ vs. control; ${ }^{* *} \mathrm{P}<0.01$ vs. control.
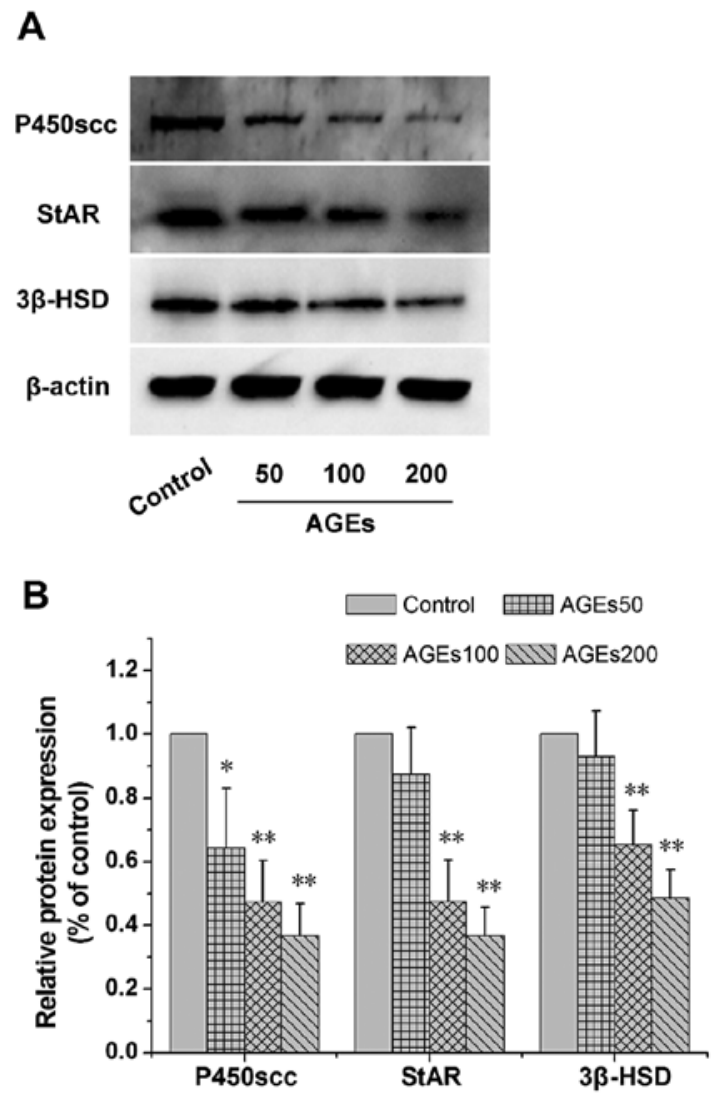

Figure 4. Effects of advanced glycation end products (AGEs) on the protein expression of cholesterol side-chain cleavage enzyme ( $\mathrm{P} 450 \mathrm{scc}$ ), steroidogenic acute regulatory protein (StAR) and $3 \beta$-hydroxysteroid dehydrogenase ( $3 \beta$ HSD). (A) Rat Leydig cells were exposed to various concentration of AGEs (50, 100 and $200 \mu \mathrm{g} / \mathrm{ml})$ for $24 \mathrm{~h}$ and the protein levels of P450scc, StAR and $3 \beta$-HSD of cells were measured by western blot analysis. (B) The levels of P450scc, StAR and 3 $\beta$-HSD were downregulated significantly following treatment with AGEs. $\mathrm{P}<0.05$ vs. control, ${ }^{* *} \mathrm{P}<0.01$ vs. control.

Oxidative stress is involved in the AGE-induced inhibition of testosterone secretion. Since oxidative stress plays an important

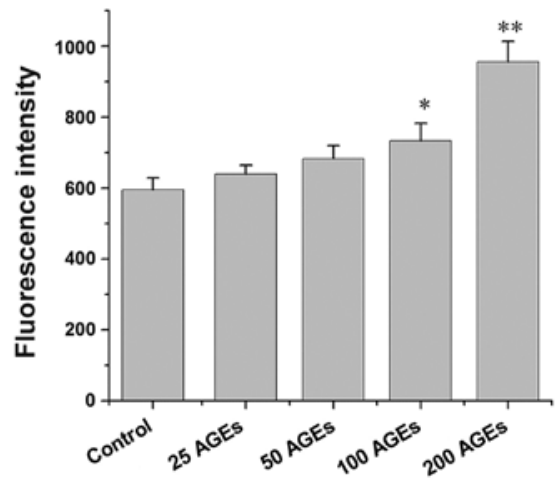

Figure 5. Effect of advanced glycation end products (AGEs) on the intensity of DCF fluorescence in Leydig cells. Rat Leydig cells were incubated with various concentrations of AGEs for $24 \mathrm{~h}$ and then loaded with dichlorofluorescein for $30 \mathrm{~min}$. Fluorescence intensity was measured and the results are shown as the means \pm SEM of 3 separate experiments. ${ }^{*} \mathrm{P}<0.05$ vs. control; ${ }^{* *} \mathrm{P}<0.01$ vs. control.

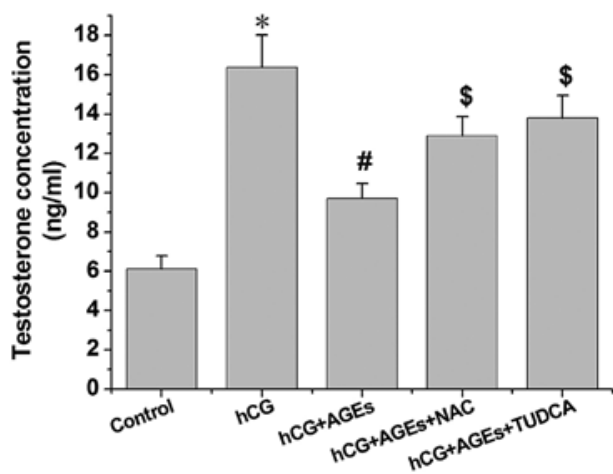

Figure 6. Effects of N-acetyl-L-cysteine (NAC) and tauroursodeoxycholic acid (TUDCA) pre-treatment on testosterone secretion by rat Leydig cells treated with AGEs. Rat Leydig cells were pre-incubated with or without NAC $(10 \mathrm{mM})$, TUDCA $(2 \mathrm{mM})$, or AGEs $(200 \mu \mathrm{g} / \mathrm{ml})$ for $1 \mathrm{~h}$ and then stimulated with human chorionic gonadotropin (hCG; $4 \mathrm{IU} / \mathrm{ml}$ ) for $24 \mathrm{~h}$. The testosterone secreted into the medium was then measured. Data are expressed as the means \pm SEM of 3 separate experiments. ${ }^{*} \mathrm{P}<0.01$ vs. control; ${ }^{*} \mathrm{P}<0.01$ vs. hCG treatment group; ${ }^{\$} \mathrm{P}<0.01$ vs. AGEs and $\mathrm{hCG}$ treatment group.

role in AGE-induced dysfunction in other tissues or cells, the role of oxidative stress in the inhibition of testosterone secretion by Leydig cells induced by AGEs was investigated. The results revealed that the AGEs significantly increased the levels of ROS in the rat Leydig cells in a concentration-dependent manner (Fig. 5). Following pre-treatment with NAC, an antioxidant agent, the inhibitory effects on testosterone secretion induced by AGEs were significantly reversed (Fig. 6).

AGEs inhibit testosterone secretion through ER stress. The Leydig cells were pre-treated with TUDCA, an endoplasmic reticulum stress inhibitor, and the levels of testosterone were measured. As shown in Fig. 6, we found that TUDCA significantly inhibited the AGE-induced decrease in the secretion of testosterone $(\mathrm{P}<0.01)$. The results of western blot analysis revealed that the expression levels of endoplasmic reticulum stress-related proteins (CHOP and GRP78) were increased (Fig. 7). In particular, following treatment with $200 \mu \mathrm{g} / \mathrm{ml}$ AGEs, the expression levels of CHOP and GRP78 were 2.40- and 2.51-fold of those of the control, respec- 
A

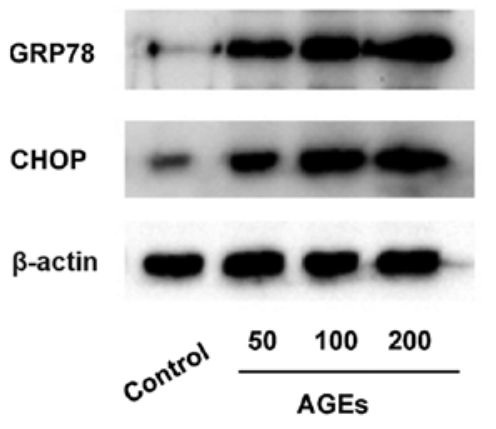

B

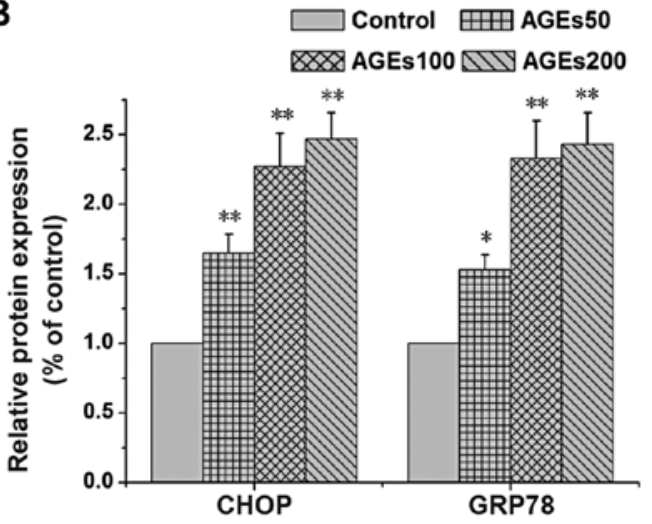

Figure 7. Effects of advanced glycation end products (AGEs) on the protein expression of C/EBP homologous protein (CHOP) and glucose-regulated protein 78 (GRP78). (A) Rat Leydig cells were exposed to various concentrations of AGEs (50, 100 and $200 \mu \mathrm{g} / \mathrm{ml}$ ) for $24 \mathrm{~h}$ and the protein levels of CHOP and GRP78 of cells were then measured by western blot analysis. (B) The levels of CHOP and GRP78 were significantly upregulated following treatment with AGEs. "P $<0.05$ vs. control. ${ }^{* *} \mathrm{P}<0.01$ vs. control.

tively $(\mathrm{P}<0.01)$. These results indicated that AGEs inhibited the synthesis of testosterone partly by inducing endoplasmic reticulum stress.

\section{Discussion}

It has been demonstrated that in diabetic men and animal models, diabetes causes reduced testosterone synthesis and secretion $(26,27)$. Several clinical and animal studies have focused on the molecular mechanisms responsible for the alterations induced by diabetes in male reproductive potential, such as endocrine disorders, neuropathy and increased oxidative stress (14). A growing body of evidence has indicated that AGEs are influential instigators, mediators and/or contributors to male reproductive dysfunction $(19,21,24,25)$. However, little is known of the role ofAGEs in Leydig cell function.

In this study, we found that AGEs decreased testosterone synthesis in rat Leydig cells induced by hCG in a dose-dependent manner. Testosterone is synthesized from cholesterol in Leydig cells. Cholesterol, synthesized de novo in the testes is transported from the outer to the inner mitochondrial membrane by StAR. Transport across the mitochondrial membrane is the rate limiting step of testosterone biosynthesis (31). P450scc mediates the conversion of cholesterol to pregnenolone on the inner mitochondrial membrane, while the conversion of pregnenolone to progesterone is carried out by $3 \beta-\mathrm{HSD}$ (32). In this study,, expression levels of StAR, P450scc and 3 $\beta$-HSD were investigated. We observed that StAR, P450scc, 3 $3-\mathrm{HSD}$ expression was significantly downregulated in the Leydig cells treated with AGEs both at the mRNA and protein level. These results indicated that the AGE-induced decrease in testosterone secretion was in part due to the inhibition of StAR, P450scc and $3 \beta$-HSD expression.

Little is known about the mechanisms through which AGEs inhibit testosterone synthesis and downregulate the expression of StAR, P450sce and 3 $\beta$-HSD. A growing body of evidence has incicatd that AGEs exacerbate disease progression through two general mechanisms, cross-linking intracellular, as well as extracellular matrix proteins, and through binding to their cell surface receptor, RAGE (33-35). The extracellular effects of AGE include the modification of structural proteins, usually connective tissue components, leading to the alteration of structure and function. On the other hand, AGEs bind RAGE and activate multiple signaling pathways, such as ROS, p21ras, ERK1/2 (p44/p42) mitogen-activated protein kinases, p38 and SAPK/JNK mitogen-activated protein kinases, phosphoinositol-3 kinase and the JAK/STAT pathways, with important downstream inflammatory consequences, such as the activation of nuclear factor- $\kappa \mathrm{B}(\mathrm{NF}-\mathrm{\kappa B})(16,33)$.

The enhancement of oxidative stress via the activation of RAGE plays a pivotal role in the pathogenesis of diabetes complications $(24,36,37)$. In this study, the effect of AGEs on oxidative stress in Leydig cells was examined. We found that AGEs significantly increased the generation of ROS in rat Leydig cells in a concentration-dependent manner. Pre-treatment with the antioxidant agent, NAC, reversed the inhibitory effects of AGEs on the synthesis of testosterone $(\mathrm{P}<0.01)$. These results demonstrated that AGEs inhibited the generation of testosterone partly by inducing oxidative stress.

Furthermore, recent studies have indicated that AGEs can also adversely affect endoplasmic reticulum function, leading to pathogenic endoplasmic reticulum stress (38-41). Inhibitors of advanced glycation acting as potent endoplasmic reticulum stress modulators with beneficial effects in restoring endoplasmic reticulum homeostasis and adjusting the physiological unfolded protein response level, present an emerging therapeutic approach with significant applications, particularly in the context of metabolic dysfunction (42). In this study, rat Leydig cells were pre-treated with TUDCA, an endoplasmic reticulum stress inhibitor, and the levels of testosterone were measured. The result revealed that TUDCA significantly inhibited the AGE-induced decrease in testosterone secretion $(\mathrm{P}<0.01)$. To further investigate the role of endoplasmic reticulum stress in the AGE-induced inhibition of testosterone secretion by Leydig cells, the expression levels of endoplasmic reticulum stressrelated protein, endoplasmic reticulum chaperone GRP78 and the transcription factor CHOP were examined by western blot analysis. The results revealed that the expression of endoplasmic reticulum stress-related protein CHOP and GRP78 was markedly upregulated following treatmetn with AGEs. It can thus 
be inferred that AGEs inhibited the generation of testosterone partly by inducing endoplasmic reticulum stress.

In conclusion, the present study demonstrates that AGEs inhibit testosterone secretion by rat Leydig cells in dose-dependent manner. The decrease in testosterone production induced by AGEs possibly occurs through the induction of oxidative stress and endoplasmic reticulum stress, and by a decrease in the levels of StAR, 3 $\beta$-HSD and P450scc in Leydig cells. This study reveals the mechanisms underlying the inhibitory effects of AGEs on testosterone secretion by rat Leydig cells and provides the basis for further investigation of male reproductive disorders caused by diabetes.

\section{Acknowledgements}

This study was supported by the Project of Enhancing School with Innovation of Guangdong Ocean University (GDOU2015050222) and grants from the Natural Science Foundation of Guangdong Ocean University (nos. 0812270, and 1212340).

\section{References}

1. Guariguata L, Whiting DR, Hambleton I, Beagley J, Linnenkamp U and Shaw JE: Global estimates of diabetes prevalence for 2013 and projections for 2035. Diabetes Res Clin Pract 103: 137-149, 2014.

2. Pinhas-Hamiel O, Dolan LM, Daniels SR, Standiford D, Khoury PR and Zeitler P: Increased incidence of non-insulin-dependent diabetes mellitus among adolescents. J Pediatr 128: 608-615, 1996.

3. Pinhas-Hamiel $\mathrm{O}$ and Zeitler P: The global spread of type 2 diabetes mellitus in children and adolescents. J Pediatr 146 693-700, 2005

4. Nadeau K and Dabelea D: Epidemiology of type 2 diabetes in children and adolescents. Endocr Res 33: 35-58, 2008.

5. Urakami T, Kubota S, Nitadori Y, Harada K, Owada M and Kitagawa T: Annual incidence and clinical characteristics of type 2 diabetes in children as detected by urine glucose screening in the Tokyo metropolitan area. Diabetes Care 28: 1876-1881, 2005.

6. Jangir RN and Jain GC: Diabetes mellitus induced impairment of male reproductive functions: a review. Curr Diabetes Rev 10 147-157, 2014.

7. Sexton WJ and Jarow JP: Effect of diabetes mellitus upon male reproductive function. Urology 49: 508-513, 1997.

8. Baccetti B, La Marca A, Piomboni P, Capitani S, Bruni E, Petraglia $\mathrm{F}$ and De Leo V: Insulin-dependent diabetes in men is associated with hypothalamo-pituitary derangement and with impairment in semen quality. Hum Reprod 17: 2673-2677, 2002.

9. Schoeller EL, Schon S and Moley KH: The effects of type 1 diabetes on the hypothalamic, pituitary and testes axis. Cell Tissue Res 349: 839-847, 2012.

10. Scarano WR, Messias AG, Oliva SU, Klinefelter GR and Kempinas WG: Sexual behaviour, sperm quantity and quality after short-term streptozotocin-induced hyperglycaemia in rats. Int J Androl 29: 482-488, 2006.

11. Agbaje IM, Rogers DA, McVicar CM, McClure N, Atkinson AB, Mallidis C and Lewis SE: Insulin dependant diabetes mellitus: implications for male reproductive function. Hum Reprod 22 : 1871-1877, 2007.

12. Ricci G, Catizone A, Esposito R, Pisanti FA, Vietri MT and Galdieri M: Diabetic rat testes: morphological and functional alterations. Andrologia 41: 361-368, 2009.

13. Mallidis C, Agbaje I, McClure N and Kliesch S: The influence of diabetes mellitus on male reproductive function: a poorly investigated aspect of male infertility. Urologe A 50: 33-37, 2011 (In German)

14. La Vignera S, Condorelli R, VicariE, D'Agata R and Calogero AE: Diabetes mellitus and sperm parameters. J Androl 33: 145-153, 2012.

15. Alves MG, Martins AD, Cavaco JE, Socorro S and Oliveira PF: Diabetes, insulin-mediated glucose metabolism and Sertoli/bloodtestis barrier function. Tissue Barriers 1: e23992, 2013.
16. Vlassara $\mathrm{H}$ and Uribarri J: Advanced glycation end products (AGE) and diabetes: cause, effect, or both? Curr Diab Rep 14: 453, 2014.

17. Vlassara H and Striker GE: Advanced glycation endproducts in diabetes and diabetic complications. Endocrinol Metab Clin North Am 42: 697-719, 2013.

18. Vlassara $\mathrm{H}$ and Striker GE: AGE restriction in diabetes mellitus: a paradigm shift. Nat Rev Endocrinol 7: 526-539, 2011.

19. Mallidis C, Agbaje I, Rogers D, Glenn J, McCullough S, Atkinson AB, Steger K, Stitt A and McClure N: Distribution of the receptor for advanced glycation end products in the human male reproductive tract: prevalence in men with diabetes mellitus. Hum Reprod 22: 2169-2177, 2007.

20. Moschonas DP, Piperi C, Korkolopoulou P, Levidou G, Kavantzas N, Trigka EA, Vlachos I, Arapostathi C, Perrea D, Mitropoulos D, et al: Impact of diet-induced obesity in male mouse reproductive system: the role of advanced glycation end product-receptor for advanced glycation end product axis. Exp Biol Med (Maywood) 239: 937-947, 2014.

21. Mallidis C, Agbaje IM, Rogers DA, Glenn JV, Pringle R, Atkinson AB, Steger K, Stitt AW and McClure N: Advanced glycation end products accumulate in the reproductive tract of men with diabetes. Int J Androl 32: 295-305, 2009.

22. O'Neill J, Czerwiec A, Agbaje I, Glenn J, Stitt A, McClure N and Mallidis C: Differences in mouse models of diabetes mellitus in studies of male reproduction. Int J Androl 33: 709-716, 2010.

23. Mallidis C, Czerwiec A, Filippi S, O'Neill J, Maggi M and McClure N: Spermatogenic and sperm quality differences in an experimental model of metabolic syndrome and hypogonadal hypogonadism. Reproduction 142: 63-71, 2011.

24. Karimi J, Goodarzi MT, Tavilani H, Khodadadi I and Amiri I: Relationship between advanced glycation end products and increased lipid peroxidation in semen of diabetic men. Diabetes Res Clin Pract 91: 61-66, 2011.

25. Karimi J, Goodarzi MT, Tavilani H, Khodadadi I and Amiri I: Increased receptor for advanced glycation end products in spermatozoa of diabetic men and its association with sperm nuclear DNA fragmentation. Andrologia 44 (Suppl 1): 280-286, 2012.

26. Cheung KK, Luk AO, So WY, Ma RC, Kong AP, Chow FC and Chan JC: Testosterone level in men with type 2 diabetes mellitus and related metabolic effects: a review of current evidence. J Diabetes Investig 6: 112-123, 2015.

27. El Baba K and Azar ST: Low testosterone and diabetes. Curr Diabetes Rev 9: 418-421, 2013.

28. Iwashima Y, Eto M, Horiuchi S and Sano H: Advanced glycation end product-induced peroxisome proliferator-activated receptor gamma gene expression in the cultured mesangial cells. Biochem Biophys Res Commun 264: 441-448, 1999.

29. Chemes H, Cigorraga S, Bergadá C, Schteingart H, Rey R and Pellizzari E: Isolation of human Leydig cell mesenchymal precursors from patients with the androgen insensitivity syndrome: testosterone production and response to human chorionic gonadotropin stimulation in culture. Biol Reprod 46: 793-801, 1992.

30. Klinefelter GR, Hall PF and Ewing LL: Effect of luteinizing hormone deprivation in situ on steroidogenesis of rat Leydig cells purified by a multistep procedure. Biol Reprod 36: 769-783, 1987.

31. Bose HS, Lingappa VR and Miller WL: The steroidogenic acute regulatory protein, StAR, works only at the outer mitochondrial membrane. Endocr Res 28: 295-308, 2002.

32. Payne AH and Hales DB: Overview of steroidogenic enzymes in the pathway from cholesterol to active steroid hormones. Endocr Rev 25: 947-970, 2004.

33. Ott C, Jacobs K, Haucke E, Navarrete Santos A, Grune T and Simm A: Role of advanced glycation end products in cellular signaling. Redox Biol 2: 411-429, 2014.

34. Jahan $\mathrm{H}$ and Choudhary MI: Glycation, carbonyl stress and AGEs inhibitors: a patent review. Expert Opin Ther Pat 25: 1267-1284, 2015.

35. Jin X, Yao T, Zhou Z, Zhu J, Zhang S, Hu W and Shen C: Advanced glycation end products enhance macrophages polarization into M1 phenotype through activating RAGE/NF- $\kappa \mathrm{B}$ pathway. BioMed Res Int 2015: 732450, 2015.

36. Amaral S, Oliveira PJ and Ramalho-Santos J: Diabetes and the impairment of reproductive function: possible role of mitochondria and reactive oxygen species. Curr Diabetes Rev 4: 46-54, 2008

37. Wautier MP, Chappey O, Corda S, Stern DM, Schmidt AM and Wautier JL: Activation of NADPH oxidase by AGE links oxidant stress to altered gene expression via RAGE. Am J Physiol Endocrinol Metab 280: E685-E694, 2001. 
38. Rong G, Tang X, Guo T, Duan N, Wang Y, Yang L, Zhang J and Liang X: Advanced oxidation protein products induce apoptosis in podocytes through induction of endoplasmic reticulum stress. J Physiol Biochem 71: 455-470, 2015.

39. Xu J, Xiong M, Huang B and Chen H: Advanced glycation end products upregulate the endoplasmic reticulum stress in human periodontal ligament cells. J Periodontol 86: 440-447, 2015.

40. Wu L, Wang D, Xiao Y, Zhou X, Wang L, Chen B, Li Q, Guo X and Huang Q: Endoplasmic reticulum stress plays a role in the advanced glycation end product-induced inflammatory response in endothelial cells. Life Sci 110: 44-51, 2014.
41. Liu J, Huang K, Cai GY, Chen XM, Yang JR, Lin LR, Yang J, Huo BG, Zhan J and He YN: Receptor for advanced glycation end-products promotes premature senescence of proximal tubular epithelial cells via activation of endoplasmic reticulum stress-dependent p21 signaling. Cell Signal 26: 110-121, 2014.

42. PiperiC, Adamopoulos C, Dalagiorgou G,Diamanti-Kandarakis E and Papavassiliou AG: Crosstalk between advanced glycation and endoplasmic reticulum stress: emerging therapeutic targeting for metabolic diseases. J Clin Endocrinol Metab 97: 2231-2242, 2012. 